

\title{
Zastosowanie implantu ucha środkowego Cochlear MET w kompensacji niedosłuchu typu mieszanego - studium przypadku
}

\section{The Cochlear MET middle ear implant in mixed hearing loss - a case study}

\author{
Henryk Skarżyński ${ }^{1 \mathrm{AD}}$, Anna Ratuszniak ${ }^{1 \mathrm{BE}}$, Kamila Osińska $^{1 \mathrm{DE}}$, \\ Łukasz Olszewski ${ }^{1 C E}$, Piotr Henryk Skarżyński ${ }^{1,2,3 A F}$ \\ ${ }^{1}$ Instytut Fizjologii i Patologii Słuchu, Światowe Centrum Słuchu, Warszawa/Kajetany \\ ${ }^{2}$ Instytut Narządów Zmysłów, Warszawa/Kajetany \\ ${ }^{3}$ Warszawski Uniwersytet Medyczny, Zakład Niewydolności Serca i Rehabilitacji \\ Kardiologicznej, Warszawa
}

\section{Streszczenie}

Wstęp: System Cochlear MET jest aktywnym implantem ucha środkowego mającym zastosowanie w kompensacji niedosłuchów typu odbiorczego i mieszanego od umiarkowanego do znacznego stopnia.

Opis przypadku: Przedstawione doniesienie zawiera charakterystykę urządzenia wszczepialnego, opis zastosowanej procedury chirurgicznej, jak również uzyskane wyniki badań audiometrycznych i ankietowych u 60-letniego mężczyzny z obustronnym umiarkowanym ubytkiem słuchu typu mieszanego, któremu w 2014 roku w Światowym Centrum Słuchu w Kajetanach wszczepiono jednostronnie system Cochlear MET do ucha lewego.

Wnioski: Uzyskane wyniki przeprowadzonych badań dowodzą skuteczności zastosowanego rozwiązania w przedstawionym przypadku pacjenta w zakresie poprawy czułości słuchu i percepcji mowy w badanym okresie obserwacji. Dane ankietowe dostarczyły informacji o subiektywnej poprawie oceny pacjenta w zakresie zdolności do komunikowania się, jakości percypowanego dźwięku oraz szumów otoczenia w protezie Cochlear MET.

Słowa kluczowe: implant ucha środkowego • Cochlear MET • niedosłuch mieszany

Abstract

Background: The Cochlear MET system is an active middle ear implant, which can be used in sensorineural and mixed hearing loss, mild to severe.

Case Report: This report contains the description of the MET system, the applied surgical procedure as well as audiometric and questionnaire-based results of a 60-year-old male patient with bilateral moderate mixed hearing loss. In 2014 at the World Hearing Center in Kajetany (Poland) the MET system was im $\neg$ planted in his left ear.

Conclusions: In the case of the presented patient, post-implantation results of the administered tests confirm the effectiveness of the device, as indicated by improved hearing and speech understanding thresholds over the observation period considered in the study. Data obtained from questionnaires reveal that in the subjective opinion of the patient, the Cochlear MET system improves his verbal communication skills, quality of the perceived sound and hearing in environmental noise.

Key words: middle ear implant $\bullet$ Cochlear MET $\bullet$ mixed hearing loss

\section{Wstęp}

Za podstawową metodę poprawy słuchu w przypadku niedosłuchu przewodzeniowego i mieszanego uznaje się leczenie chirurgiczne, którego efekty zależą od wielu czynników. Pomimo zadowalających w większości przypadków wyników uzyskiwanych za pomocą tej metody leczenia, istnieją sytuacje, w których rezultaty są niesatysfakcjonujące 
lub nietrwałe. Ma to miejsce głównie w przypadku przewlekłych zmian zapalnych w obrębie ucha środkowego oraz wad wrodzonych [1,2]. W przypadku gdy możliwości uzyskania dobrych efektów dzięki operacjom poprawiającym słuch zostają wyczerpane, sposobem na poprawę czułości słyszenia i rozumienia mowy staje się protezowanie słuchu. Do jednej z form takiego protezowania zalicza się implanty ucha środkowego, do których należy system Cochlear MET. Ich zasada działania opiera się w uproszczeniu na transformacji energii akustycznej w energię mechaniczną, przekazywaną dalej do wybranych struktur ucha środkowego za pomocą specjalnego przetwornika drgającego [3].

Niniejsza praca prezentuje pierwsze w Polsce zastosowanie opisywanego systemu implantu ucha środkowego Cochlear MET u pacjenta z mieszanym ubytkiem słuchu.

\section{Material i metody}

\section{Opis przypadku}

Mężczyzna, lat 60, zgłosił się do Kliniki Oto-Ryno-Laryngochirurgii Instytutu Fizjologii i Patologii Słuchu w celu leczenia niedosłuchu. W wywiadzie odnotowano występujące od dzieciństwa obustronne przewlekłe stany zapalne ucha środkowego z towarzyszącym wyciekiem, stopniowe pogorszenie słuchu i szumy uszne. Liczne operacje wykonywane w przeszłości, mające na celu poprawę słyszenia, nie przyniosły oczekiwanego rezultatu. Okresowe wycieki z uszu ograniczały możliwości systematycznego i długoczasowego korzystania $\mathrm{z}$ aparatów słuchowych na przewodnictwo powietrzne, które wymuszały zastosowanie wkładki zamkniętej uniemożliwiającej wentylowanie przewodu słuchowego. $Z$ uwagi na dotychczasowy przebieg choroby pacjent został skierowany na badania diagnostyczne w kierunku zastosowania urządzeń wszczepialnych.

\section{Rozpoznanie i zastosowane metody diagnostyczne oraz leczenie}

W badaniu przedmiotowym ucha lewego - stan po dwóch operacjach tympanoplastycznych - myringoplastykach, przeszczepy wgojone, ucho zamknięte, suche, w uchu prawym widoczna perforacja subtotalna, ucho nieco wilgotne, pacjent oczekuje na operację rekonstrukcyjną. Podczas wizyty wykonano audiometrię tonalną i słowną. W audiometrii tonalnej średnia wartość progu słyszenia dla częstotliwości 500, 1000, 2000 i $4000 \mathrm{~Hz}$ wynosiła 69 dB HL dla ucha prawego oraz $60 \mathrm{~dB}$ HL dla ucha lewego. Zgodnie z klasyfikacją ubytków słuchu zaproponowaną przez Międzynarodowe Biuro Audiofonologii [4], niedosłuch pacjenta określono jako obustronnie umiarkowany. Testy rozumienia mowy wykonano z użyciem list słów jednosylabowych Demenko i Pruszewicza. Uzyskany stopień rozumienia mowy wynosił $50 \%$ i $85 \%$ odpowiednio dla ucha prawego i lewego. Z uwagi na stan miejscowy oraz uzyskane wyniki badań diagnostycznych do implantacji wybrano ucho lewe.

W październiku 2014 roku pacjent został poddany operacji wszczepienia systemu implantu ucha środkowego Cochlear MET.
W celu oceny skuteczności zastosowanego urządzenia wykonano badania progów słyszenia oraz stopnia dyskryminacji mowy w polu swobodnym przed implantacją oraz w optymalnie dopasowanym procesorze dźwięku. Audiometryczne badanie progowe wykonano dla sygnałów z zakresu 250-4000 Hz w odstępie jednej oktawy. Badanie powtórzono $\mathrm{w}$ interwałach czasowych 1, 3 i 12 miesięcy od aktywacji urządzenia. W celu oceny zysku dyskryminacji mowy wykonano badanie audiometrii słownej w polu swobodnym dla poziomów natężenia prezentowanego sygnału 50, 60 i $70 \mathrm{~dB}$ SPL w warunkach ciszy przed implantacją oraz po 3 i 12 miesiącach od aktywacji systemu. W celu oceny efektywności zastosowanego systemu wykonano kwestionariuszową ocenę słyszenia przy użyciu kwestionariusza APHAB (Abbreviated Profile of Hearing Aid Benefit) wypełnionego przed zabiegiem implantacji oraz po 12 miesiącach od aktywacji urządzenia. Kwestionariusz APHAB składa się z 24 pytań i jest samooceną, w której pacjent zgłasza liczbę problemów ze słyszeniem i rozumieniem mowy w różnych warunkach akustycznych. Zysk oblicza się na podstawie różnic w liczbie problemów identyfikowanych przez pacjenta przed zaprotezowaniem i po zaprotezowaniu (rycina 1) [5].

\section{Opis urządzenia Cochlear MET}

Urządzenie Cochlear MET składa się z części wewnętrznej i zewnętrznej. Część wewnętrzna umieszczana jest przez chirurga podskórnie w loży kostnej, na granicy kości skroniowej i ciemieniowej. Składa się ona $\mathrm{z}$ kapsuły z cewką odbiorczą, wybranymi podzespołami elektronicznymi i magnetycznymi oraz $\mathrm{z}$ połączonego $\mathrm{z}$ nią przewodem elektromagnetycznego przetwornika drgającego wraz z odpowiednim systemem mocującym do kości czaszki. Część zewnętrzna zawiera magnes, cewkę nadawczą oraz audioprocesor zaopatrzony w mikrofony odbierające z zewnątrz sygnał akustyczny, który po przetworzeniu sygnału na podstawie zadanego algorytmu przekazuje go przezskórnie drogą radiową do części wewnętrznej systemu. Dostarczona w ten sposób energia zamieniana jest przez część wewnętrzną na drgania przetwornika sprzężonego $\mathrm{z}$ wybraną strukturą ucha środkowego. Procesor utrzymywany jest na skórze dzięki sile wzajemnego przyciągania magnesów umieszczonych w części wewnętrznej oraz zewnętrznej (rycina 2).

\section{Zastosowanie i wskazania do systemu Cochlear MET}

Rozwiązanie znajduje zastosowanie w przypadku pacjentów z niedosłuchem odbiorczym i mieszanym [6]. Implanty ucha środkowego początkowo przeznaczone były dla niedosłuchów odbiorczych w tych przypadkach, w których nie było możliwości zastosowania klasycznych aparatów słuchowych m.in. wskutek alergii na materiał wkładki czy zapaleń przewodu słuchowego zewnętrznego lub silnego efektu okluzji [7]. Od 2006 roku wskazania do zastosowania implantów ucha środkowego uległy rozszerzeniu o niedosłuchy typu przewodzeniowego i mieszanego. Pierwszy raport na temat zastosowania implantu ucha środkowego w niedosłuchu innym niż odbiorczy dotyczył implantacji systemu Vibrant Soundbridge firmy Med-El na okienko okrąłe [8]. Jak wskazuje literatura, implanty ucha środkowego, zarówno Vibrant Soundbridge jak i MET, stosowane są w leczeniu niedosłuchów mieszanych [9-12]. 

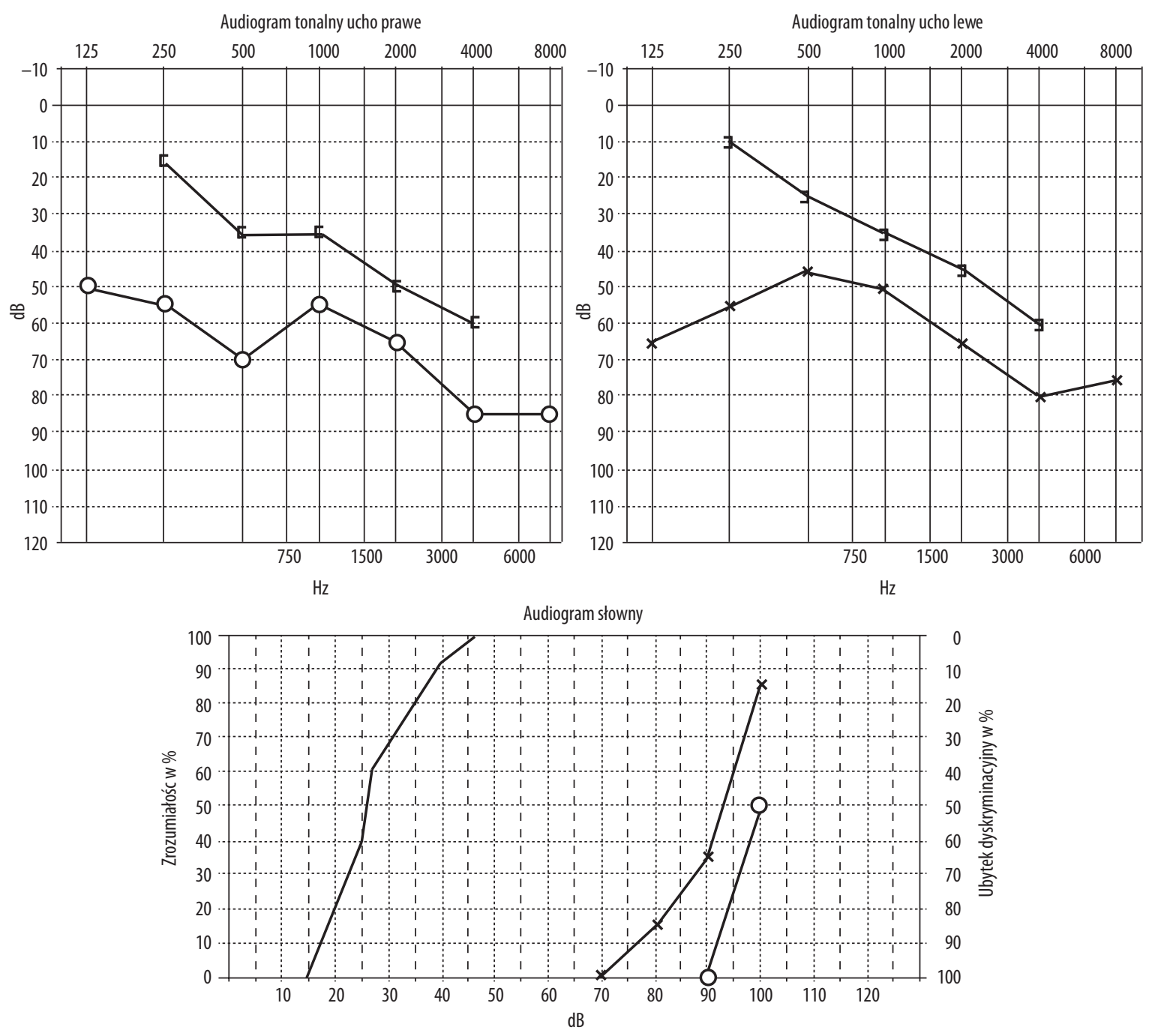

Rycina 1. Wyniki badań audiometrii tonalnej oraz słownej

Figure1. The results of pure-tone audiometry and speech audiometry

\section{Cochlear"ME"S System}



Następnie wykonano attykoantromastoidektomię odpowiednio rozszerzoną, aby móc umiejscowić tytanowy pierścień mocujący część implantu. Po umocowaniu wewnętrznej części implantu dopasowano ułożenie sztyftu na odnodze krótkiej kowadełka. Jednoczasowo dokonywano analizy przylegania sztyftu za pomocą odpowiedniego urządzenia. Po stwierdzeniu właściwego przylegania do kosteczki, za pomocą specjalnego śrubokrętu dokręcono śrubę o $1 / 4$ obrotu. Wykonano ponowny pomiar w celu stwierdzenia właściwej stymulacji. Zastosowano klasyczną metodę kontaktu z łańcuchem kosteczek słuchowych. W niektórych przypadkach istnieje możliwość zastosowania zamiast sztyftu różnego rodzaju couplerów (na okienko okrągłe, rękojeść młoteczka czy główkę strzemiączka). Miesiąc po zabiegu dopasowano i podłączono zewnętrzny procesor dźwięku (ryciny 3-15).

\section{Okres pooperacyjny}

Okres pooperacyjny przebiegał bez powikłań. Pacjent został wypisany do domu z zaleceniem kontroli po 10 dniach $\mathrm{w}$ ambulatorium przyszpitalnym Instytutu Fizjologii do tyłu od małżowiny usznej. Cięcie musi być większe w stosunku do innych implantów ucha środkowego w związku z wielkością części podskórnej implantu. 


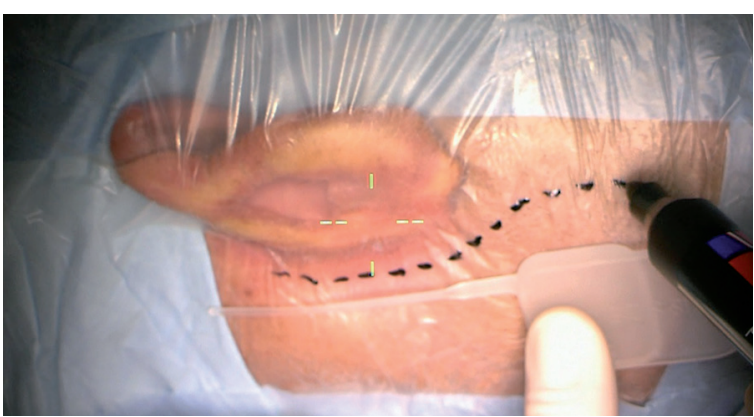

Rycina 3. Przyłożenie przymiaru części podskórnej w celu zaplanowania wielkości cięcia skórnego w okolicy zamałżowinowej

Figure 3. Planning of the skin size of the incision in the retroauricular area with the use of the gauge measuring the subcutaneus layer



Rycina 4. Cięcie skóry i odpreparowanie płata skórno-mięśniowego, okostnej z okolicy zamałżowinowej

Figure 4. Skin incision and dissection of a skin-muscle flap and the periosteum in the retroauricular area

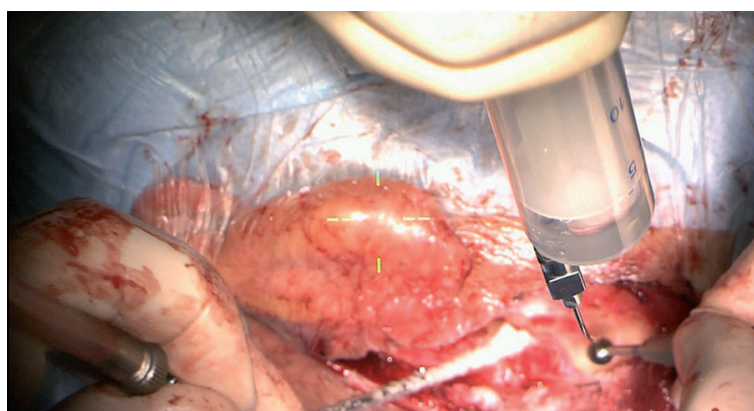

Rycina 5. Wypreparowanie loży kostnej na granicy kości ciemieniowej i skroniowej dla kapsuły części podskórnej

Figure 5. Drilling of the bony bed for the electronic capsule on the border of the parietal and temporal bone

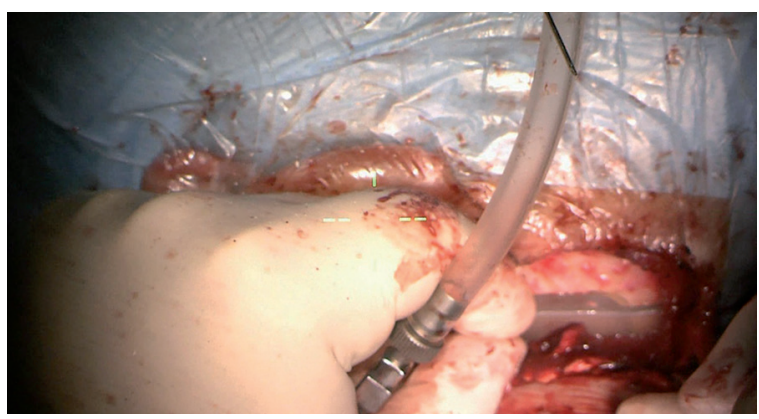

Rycina 6. Weryfikacja wielkości i głębokości loży kostnej dla kapsuły przy użyciu przymiaru

Figure 6. Checking of the size and depth of the bony bed for the capsule with the use of the gauge

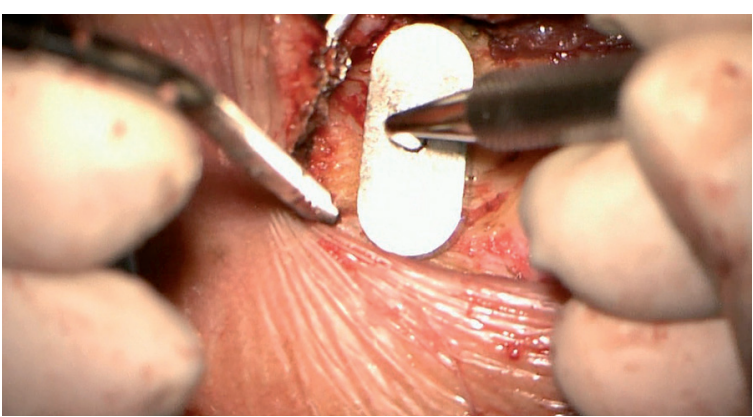

Rycina 7. Planowanie wielkości jamy w wyrostku dla mocowania przy użyciu przymiaru

Figure 7. Planning of the size of a pilot hole in the in mastoid for the fixation part with the use of the atticotomy template

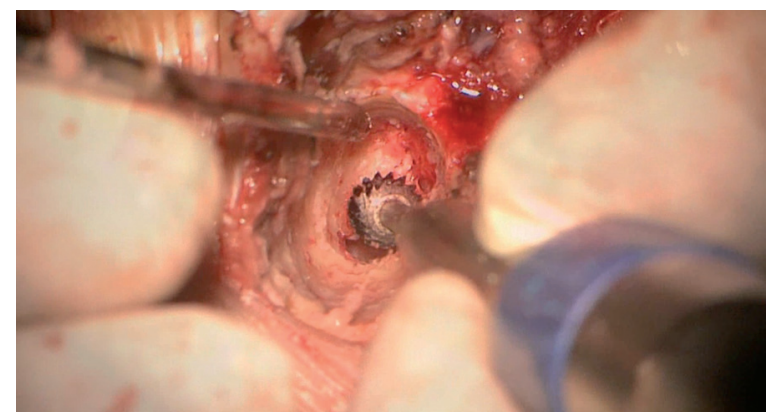

Rycina 8. Wykonanie attykotomii tylnej

Figure 8. Drilling for posterior atticotomy



Rycina 9. Uwidocznienie trzonu i odnogi krótkiej kowadełka

Figure 9. The exposure of the short process and the body of the incus

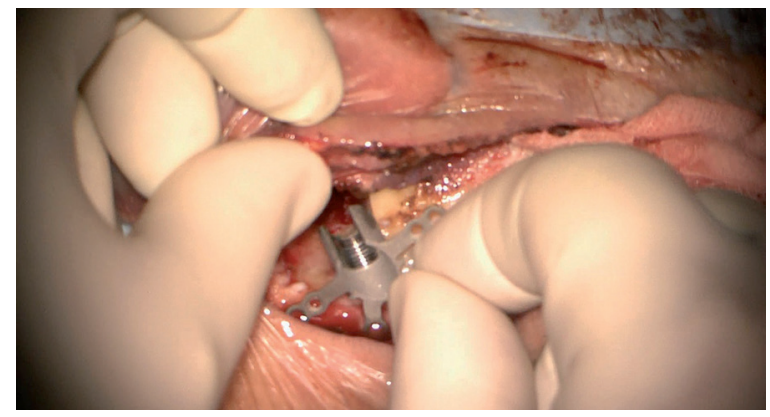

Rycina 10. Wstępne usytuowanie mocowania w loży kostnej Figure 10. A preliminary location of the fixation part 


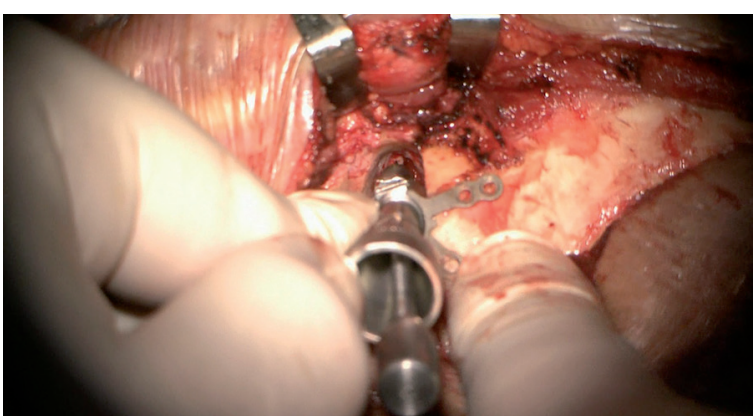

Rycina 11. Przyłożenie wzornika przetwornika i jego wkręcenie celem uzyskania styku z trzonem kowadełka

Figure 11. Placing the actuator template and its fixation in order to obtain contact with the body of the incus

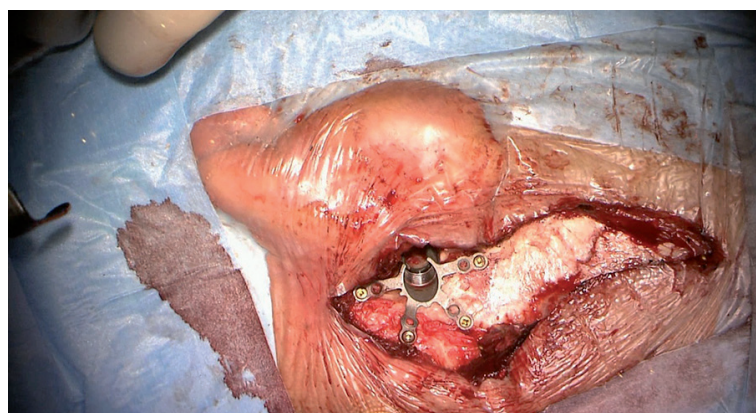

Rycina 12. Umocowanie 4 ramion systemu stabilizującego za pomocą śrub

Figure 12. Fixation of 4 arms of the stabilising system with the use of screws

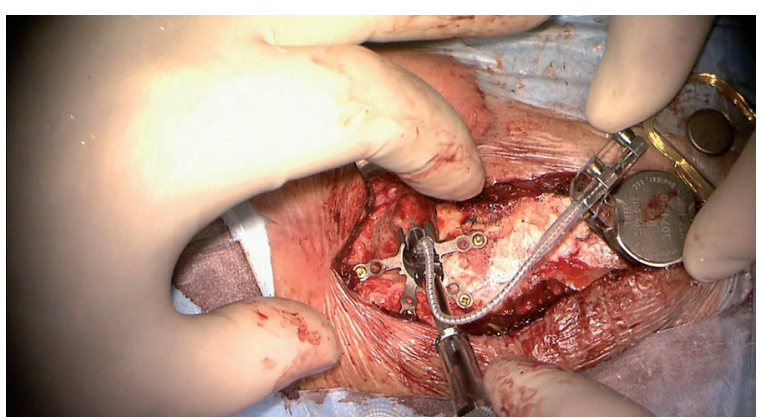

Rycina 13. Umiejscowienie i stopniowe zbliżanie właściwego przetwornika do kowadełka, z zastosowaniem śródoperacyjnego pomiaru impedancji, weryfikującego siłę nacisku aktuatora na kowadełko

Figure 13. The location and gradual approximation of the proper transducer to the incus with the use of intraoperative impedance measurement, for verifing the force exerted by the actuator by the incus

i Patologii Słuchu. Podczas ustalonej pooperacyjnej wizyty kontrolnej usunięto opatrunek, stwierdzono prawidłowe gojenie się rany i zdjęto szwy. Miesiąc po zabiegu podłączono zewnętrzny audioprocesor i dopasowano magnes zapewniający właściwe utrzymanie urządzenia.

\section{Wyniki}

Wyniki przeprowadzonych badań progowych w polu swobodnym uzyskane przed zabiegiem i po implantacji potwierdzają obniżenie progu słyszenia w zakresie badanych częstotliwości. Uzyskany wynik był stabilny w czasie (rycina 16). W audiometrii słownej w polu swobodnym również

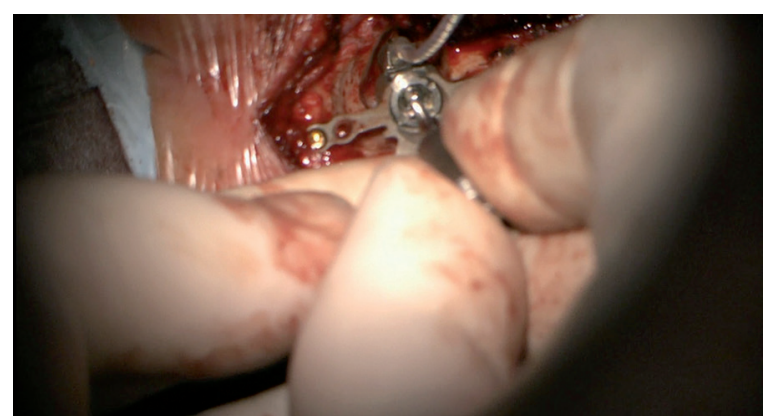

Rycina 14. Ostateczne zbliżenie aktuatora do kowadełka, z zastosowaniem techniki optymalnego styku

Figure 14. Final approximation of the actuator to the incus with the technique of optimal contact

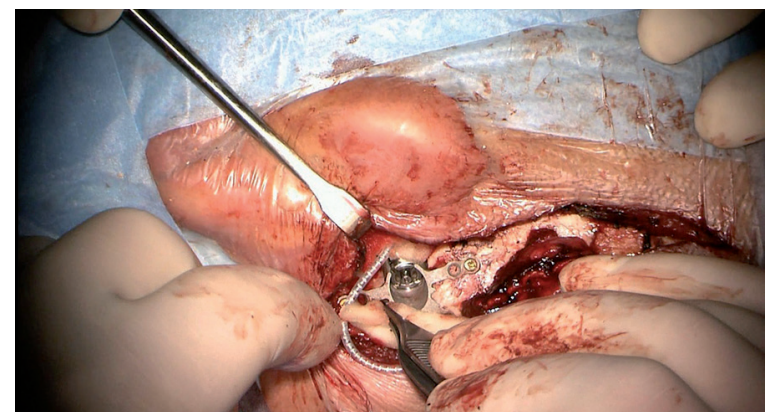

Rycina 15. Umiejscowienie kapsuły w loży kostnej, spongostan nasączony antybiotykiem $\mathrm{w}$ okolicę otworu dla przetwornika, warstwowe zszycie tkanek, opatrunek zewnętrzny

Figure 15. Location of the internal capsule in the bony bed, applying a spongostan soaked in antibiotics to the hole for the actuator, tissue suturing, external dressing

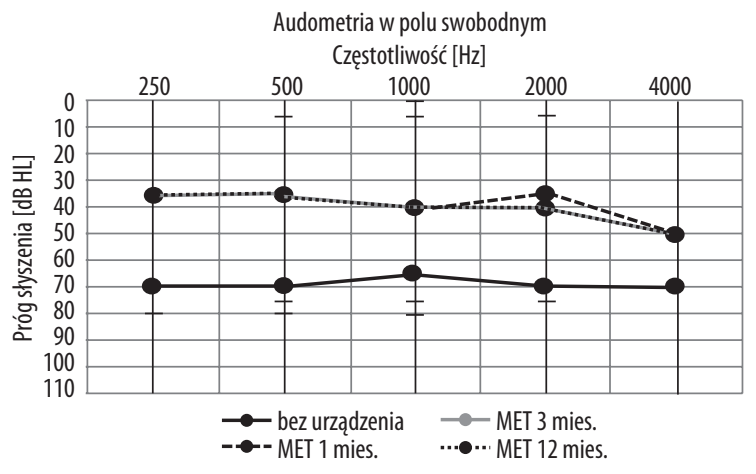

Rycina 16. Progi słyszenia uzyskane w polu swobodnym

Figure 16. Hearing thresholds in free field

odnotowano poprawę rozumienia mowy dla wszystkich badanych poziomów natężenia sygnału, a maksymalny zysk (różnica w stopniu dyskryminacji mowy uzyskanym bez urządzenia i w urządzeniu) po 3 miesiącach wynosił $75 \%$, a po 12 miesiącach $85 \%$ (rycina 17 ).

Wyniki analizy kwestionariuszy wskazują na poprawę słyszenia $\mathrm{w}$ trzech $\mathrm{z}$ czterech prezentowanych kategorii zdolności komunikowania się, słyszenia w warunkach wybrzmiewania i echa oraz słyszenia $\mathrm{w}$ warunkach szumu zakłócającego, przy czym największy zysk odnotowano 


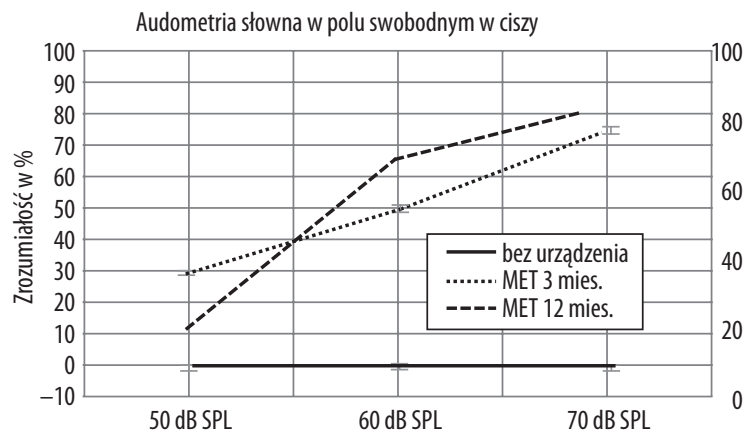

Rycina 17. Wyniki badań rozumienia mowy

Figure 17. The results of monosyllabic speech understanding

Tabela 1. Wyniki kwestionariusza APHAB

Table 1. The results of the APHAB questionnaire

\begin{tabular}{lcccc}
\hline & ZK & WY & so & NO \\
\hline Liczba problemów unaided [\%] & 97 & 99 & 97 & 35 \\
\hline Liczba problemów aided [\%] & 45 & 35 & 43 & 72 \\
\hline Zysk (unaided-aided) [\%] & 52 & 64 & 54 & -37 \\
\hline
\end{tabular}

ZK - zdolność komunikowania się; WY - wybrzmiewanie, echo; SO - szum otoczenia; NO - nieprzyjemny odbiór dźwięków.

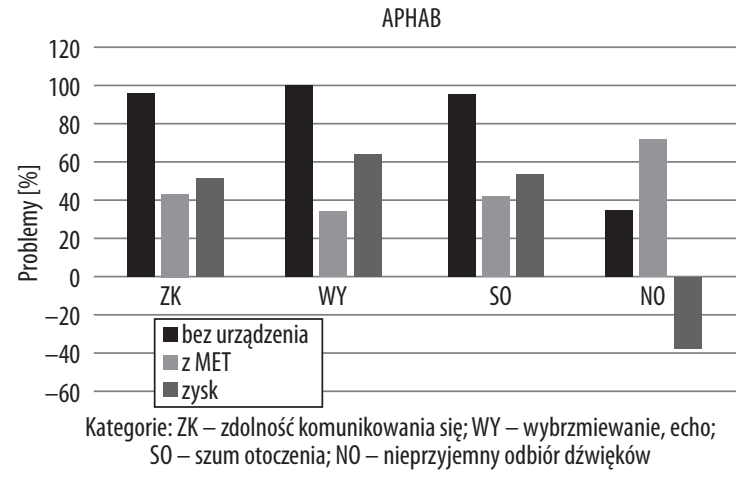

Rycina 18. Wyniki kwestionariusza APHAB

Figure 18. The results of the APHAB questionnaire

dla kategorii drugiej. Dane liczbowe analizy kwestionariusza zawiera tabela 1 (rycina 18 ).

Subiektywnie pacjent ocenia efekty zastosowanego rozwiązania jako bardzo dobre, jest zainteresowany wszczepieniem systemu MET w drugim uchu. W chwili obecnej $\mathrm{z}$ uwagi na stan miejscowy ucha prawego w pierwszej kolejności zaplanowana jest klasyczna operacja rekonstrukcyjna.

\section{Dyskusja}

W związku z rozszerzaniem wskazań do stosowania implantów ucha środkowego, coraz większa grupa pacjentów ma dostęp do wymienionych technologii. Niezwykle korzystne są modyfikacje połączenia przetwornika danego urządzenia $\mathrm{z}$ łańcuchem kosteczek słuchowych lub innymi elementami ucha środkowego. W przypadku systemu Cochlear MET z jednej strony mamy do czynienia $\mathrm{z}$ urządzeniem o stosunkowo dużym wzmocnieniu, z drugiej strony o wysokich wymaganiach pod względem anatomicznym. Niektórzy autorzy twierdzą, że nie ma istotnej różnicy pomiędzy wynikami badań uzyskanymi w implancie typu Vibrant Soundbridge a Cochlear MET [13]. Ośrodek w Hanowerze podaje, iż u 13\% pacjentów odnotowuje się zaprzestanie korzystania $\mathrm{z}$ tego typu rozwiązań w długotrwałej obserwacji [13]. Analizując wskazania oraz na podstawie własnej praktyki klinicznej, można uznać, iż system Cochlear MET można zastosować przy głębszych niedosłuchach niż w przypadku innych implantów ucha środkowego [14]. Istotnym elementem mającym wpływ na uzyskane korzyści jest właściwe umieszczenie sztyftu lub couplera w odpowiednim miejscu. Nawet niewielkie osłabienie kontaktu pomiędzy przetwornikiem a strukturą ucha środkowego może wpłynąć negatywnie na uzyskane wyniki [15]. Tego typu problem w przypadku innych urządzeń wszczepialnych do ucha środkowego występuje tylko z couplerem na okienko owalne (OW-coupler) w systemie Vibrant Soundbridge. Z uwagi na konieczność uzyskania dobrego kontaktu również czas operacji wszczepienia systemu MET znacznie się wydłuża. Znaczne wymagania anatomiczne powodują, iż u części pacjentów po wykonaniu diagnostyki radiologicznej (tomografia komputerowa kości skroniowych) odnotowuje się przeciwskazania do zastosowania tego typu rozwiązania. Pacjentom diagnozowanym w Światowym Centrum Słuchu Instytutu Fizjologii i Patologii Słuchu, u których istnieje ryzyko odsłonięcia zatoki esowatej lub kontaktu $\mathrm{z}$ oponami mózgu, nie jest zalecana tego typu operacja. Kontorinis z zespołem przeanalizowali przypadki, w których podczas wszczepienia implantu typu MET lub Carina (w przypadku implantu Carina tytanowy pierścień umieszczany jest tożsamo jak w przypadku implantu typu MET) zostały odsłonięte opony. W 9 na 10 przypadkach odległość w kości skroniowej pomiędzy tylną ścianą przewodu słuchowego zewnętrznego a oponami wynosiła poniżej $8 \mathrm{~mm}$ [16]. W związku $\mathrm{z}$ tym nie rekomenduje się implantacji opisywanego systemu w przypadkach, w których odległość ta jest mniejsza niż $8 \mathrm{~mm}$, a każdy pacjent będący kandydatem do zastosowania systemu powinien mieć wykonane badanie tomografii komputerowej.

\section{Wnioski}

W opisywanym przypadku system Cochlear MET okazał się skutecznym narzędziem kompensacji niedosłuchu mieszanego. Uzyskano stabilną w czasie poprawę słyszenia w szerokim zakresie częstotliwości oraz znaczną poprawę rozumienia mowy w warunkach ciszy. Urządzenie jest akceptowane i chętnie użytkowane przez pacjenta. Zastosowanie nowej technologii implantu ucha środkowego i uzyskane wyniki stwarzają nowe możliwości dla pacjentów z rożnymi uszkodzeniami narządu słuchu oraz zróżnicowanymi patologiami ucha zewnętrznego i środkowego. 


\section{Piśmiennictwo:}

1. Declau F, Cremers C, Van de Heyning P. Diagnosis and management strategies in congenital atresia of the external auditory canal Study Group on Otological Malformations and Hearing Impairment. Br J Audiol, 1999; 33(5): 313-27.

2. Olszewski Ł, Ratuszniak A, Obrycka A, Porowski M, Skarżyński PH, Pastuszak A i wsp. Middle Ear Implant - a chance for elimination of certain restrictions on sound reception tied with the hearing aids in the partial deafness treatment. 10 ${ }^{\text {th }}$ ESPCI Athens Medimond, 2011: 21-28.

3. Boeheim K, Pok S-M, Schloegel M, Filzmoser P. Active middle ear implant compared with open-fit hearing aid in sloping high-frequency sensorineural hearing loss. Otol Neurotol, 2010; 31(3): 424-29.

4. BIAP - Bureau International d'Audiophonologie - BIAP Bureau International d'Audiophonologie, https://www.biap. org/en/component/content/article/65-recommendations/ ct-2-classification/5-biap-recommendation-021-bis.

5. Cox RM, Alexander GC. The abbreviated profile of hearing aid benefit. Ear Hear, 1995; 16(2): 176-86.

6. Skarżyński H, Szkiełkowska A, Olszewski Ł, Mrówka M, Porowski M, Fabijańska A i wsp. Program stosowania implantów ucha środkowego i implantów zakotwiczonych w kości skroniowej na przewodnictwo kostne w leczeniu zaburzeń słuchu. Now Audiofonol, 2015; 4(1): 9-23.

7. Wagner F, Todt I, Wagner J, Ernst A. Indications and candidacy for active middle ear implants. Adv Otorhinolaryngol, 2010; 69: 20-26.

8. Colletti V, Soli SD, Carner M, Colletti L. Treatment of mixed hearing losses via implantation of a vibratory transducer on the round window. Int J Audiol, 2006; 45(10): 600-608.
9. Zwartenkot JW, Mulder JJS, Snik AFM, Cremers CWRJ, Mylanus EAM. Active Middle Ear Implantation: Long-term medical and technical follow-up, implant survival, and complications. Otol Neurotol, 2016; 37(5): 513-19.

10. Dumon T. Vibrant soundbridge middle ear implant in otosclerosis: technique - indication. Adv Otorhinolaryngol, 2007; 65: 320-22.

11. Venail F, Lavieille JP, Meller R, Deveze A, Tardivet L, Magnan J. New perspectives for middle ear implants: first results in otosclerosis with mixed hearing loss. The Laryngoscope, 2007; 117(3): 552-55.

12. Skarzynski H, Olszewski L, Skarzynski PH, Lorens A, Piotrowska A, Porowski M i wsp. Direct round window stimulation with the Med-El Vibrant Soundbridge: 5 years of experience using a technique without interposed fascia. Eur Arch Otorhinolaryngol, 2014; 271(3): 477-82.

13. Zwartenkot JW, Hashemi J, Cremers CWRJ, Mulder JJS, Snik AFM. Active middle ear implantation for patients with sensorineural hearing loss and external otitis: long-term outcome in patient satisfaction. Otol Neurotol, 2013; 34(5): 855-61.

14. Kasic JF, Fredrickson JM. The Otologics MET ossicular stimulator. Otolaryngol Clin North Am, 2001; 34(2): 501-13.

15. Kontorinis G, Giesemann AM, Witt T, Goetz F, Schwab B. Controlling the position and the dislocation of the middle ear transducer with high-resolution computed tomography and digital volume tomography: implications for the transducers' design. Eur Arch Otorhinolaryngol, 2012; 269(4): 1103-10.

16. Kontorinis G, Lenarz T, Schwab B. Anatomic limitations in implantation of middle ear transducer and carina middle ear implants. The Laryngoscope, 2010; 120(11): 2289-93. 